\title{
PENERAPAN PERDA NO. 1 TAHUN 2015 TENTANG BANGUNAN GEDUNG DI KOTA BUKITTINGGI
}

\author{
Gita Triana \\ Jurusan Administrasi Publik, Fakultas Ilmu Sosial, Universitas Negeri Padang \\ git4triana.ds@gmail.com \\ Afriva Khaidir \\ Jurusan Administrasi Publik, Fakultas Ilmu Sosial, Universitas Negeri Padang \\ Af.khaidir@gmail.com
}

\begin{abstract}
This study aimed to determine the implementation of the regional government No. 1 of 2015 concerning building in Bukittinggi City.The background of this research is because there are still buildings that were built without IMB, the community still builds buildings in areas that are not in accordance with the land designation, low willingness of the community to comply with regulations and there are buildings that have permits, but the construction process is not appropriate with permission that has been issued. This research is a qualitative research using descriptive method. Data collection techniques use interview techniques, field observations, and documentation studies. The informants in this study were determined through purposive techniques. Data analysis techniques can be carried out namely data collection, data reduction, data presentation, and then draw conclusions. The results showed that the implementation of the Bukittinggi City regional government policy on building permits had not yet proceeded, such as people building buildings without permits, buildings that have permits but when the construction process is carried out is not in accordance with the provisions of permits that have been issued, the lack of supervision carried out by the local apparatus organization is related. constraints faced in implementing this policy such as communication constraints in the form of uneven socialization, the resources owned by the related local apparatus organization are inadequate and the lack of willingness of the community to comply with regulations.
\end{abstract}

Keywords: implementation, public policy, building establishment permits

\section{Pendahuluan}

Kota memiliki peran yang sangat penting dalam pembangunan. Setiap pembangunan yang dilakukan di dalam suatu negara harus terarah, supaya terjadi keseimbangan, keserasian (keselarasan), berdaya guna, berhasil guna, berbudaya dan berkelanjutan dalam rangka meningkatkan kesejahteraan rakyat yang berkeadilan (Sutedi, 2010). Rencana pembangunan tata kota berarti rencana pembangunan sesuai dengan arahan-arahan yang sudah ditentukan
Bangunan gedung merupakan salah satu wujud fisik dari pemanfaatan ruang yang penyelenggaraannya haruslah berlandaskan kepada peraturan penataan ruang. Pengaturan penyelenggaraan bangunan gedung dimaksudkan agar bangunan gedung yang didirikan diawal telah ditetapkan fungsinya sehingga masyarakat yang akan mendirikan bangunan dapat memenuhi persyaratan baik administratif maupun teknis bangunan gedungnya dengan efektif dan efesien. Untuk menciptakan pembangunan yang mengacu kepada konsep penataan ruang, 


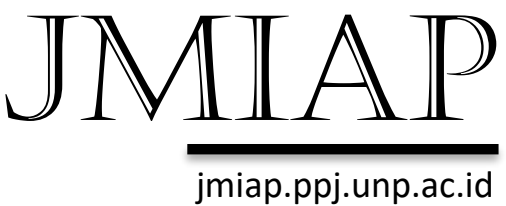

pemerintah perlu membuat peraturan yang mewajibkan seluruh masyarakat yang mendirikan bangunan untuk mengurus izin mendirikan bangunan.

Izin mendirikan bangunan Kota Bukittinggi diatur dalam Peraturan Daerah No. 1 tahun 2015 tentang bangunan gedung. Maksud dari Peraturan Daerah ini adalah sebagai pengaturan lebih lanjut dari Undang-undang Nomor 28 Tahun 2002 tentang Bangunan Gedung dan Peraturan Pemerintah Nomor 36 Tahun 2005 tentang Peraturan Pelaksana Undang-undang Nomor 28 Tahun 2002 tentang Bangunan Gedung. Dalam perda tersebut telah disebutkan bahwa setiap orang atau badan yang akan mendirikan bangunan wajib memiliki IMB dengan mengajukan permohonan izin mendirikan bangunan gedung yang dikelola oleh Dinas Penanaman Modal, Pelayanan Terpadu Satu Pintu, Perindustrian dan Tenaga Kerja. IMB berfungsi agar pemerintah daerah dapat mengontrol dalam rangka pendataan fisik kota sebagai dasar yang sangat penting bagi perencanaan, pengawasan dan penertiban pembangunan kota yang terarah dan IMB juga bermanfaat bagi pemilik bangunan karena memberikan kepastian hukum atas berdirinya bangunan yang bersangkutan dan memudahkan bagi pemilik bangunan untuk suatu keperluan, antara lain dalam hal pemindahan hak bangunan kepada pihak lain (seperti jual beli, pewarisan, penghibahan, dan sebagainya) untuk mencegah tindakan penertiban jika tidak memiliki IMB (Sutedi, 2010)

Kota Bukittinggi termasuk daerah yang rawan bencana, untuk itu perlu adanya IMB agar terciptanya tata letak bangunan yang teratur, sesuai peruntukan lahan dan aman bagi keselamatan dan kenyamanan masyarakat. Sebagaimana dalam pasal 19 ayat (1) Perda No 1 tahun 2015 disebutkan, "Bangunan gedung harus
JURNAL ILMU ADMINISTRASI PUBLIK

Email : ¡ianfis.unp@gmail.com

Vol. 1 No. 1 Tahun 2018

diselenggarakan sesuai dengan peruntukan lokasi yang telah ditetapkan dalam RTRW, RDTR dan/atau RTLB. Namun kenyataannya masyarakat masih mendirikan bangunan di daerah yang tidak diperuntukan untuk mendirikan bangunan.

Berdasarkan wawancara peneliti dengan kasi penataan ruang dinas pekerjaan umum dan penataan ruang pada tanggal 2 mei 2018 menyatakan bahwa "Secara rencana pola ruang 50M dari bibir ngarai sianok tidak boleh dibangun bangunan karena merupakan daerah sempadan ngarai yang rawan terkena bencana. Bangunan-bangunan tersebut tidak memiliki izin mendirikan bangunan. Jika masyarakat pemilik bangunan mengurus izin, maka dari kami pun tidak akan mengeluarkan izin untuk mendirikan bangunan di daerah sepanjang sempadan ngarai karena tidak sesuai peruntukan lahan dan akan membahayakan keselamatan. Kenyataannya masyarakat masih mendirikan bangunan disekitar ngarai sianok yang merupakan kawasan rawan bencana yang memiliki dampak luas terhadap kehidupan."

Fakta di lapangan menunjukkan bahwa pelaksanaan kebijakan menemui berbagai hambatan dan rintangan seperti rendahnya minat masyarakat untuk mengurus IMB. Mendirikan bangunan tidak disertai IMB membuat masyarakat merasakan sendiri dampaknya. Seperti permasalahan yang terjadi di Kota Bukittinggi, dimana dilakukan pembongkaran sebuah toko yang didirikan sejak belasan tahun lalu di atas lahan untuk jalan penghubung Jalan Parak Kubang ke Barumbuang 5, Aur Kuning, Bukittinggi karena tidak memiliki Izin Mendirikan Bangunan (IMB). Selanjutnya menurut Nurlis (53) salah seorang warga yang juga ikut menyaksikan pembongkaran juga 
menuturkan bahwa: "Ada banyak bangunan di sekeliling pasar Aur Kuning yang jelas-jelas menyalahi aturan. Banyak diantara mereka menambah bangunan dengan memakai fasilitas umum seperti jalan tanpa mengurus proses perizinanya." (Sumber: gosumbar.com 2017).

Permasalahan lain yang ditemukan di lapangan seperti bangunan yang memiliki IMB namun pada saat pelaksanaan pembangunan bangunan tersebut terjadi ketidaksesuaian dengan IMB yang telah diterbitkan. Seperti pembangunan rumah di jalan Abdul Manan, Kelurahan Campago Ipuh, Kecamatan Mandiangin Koto Selayan, Kota Bukittinggi dimana diketahui bahwasannya bangunan tersebut tidak sesuai dengan ketentuan izin mendirikan bangunan yang telah diterbitkan, bangunan tersebut telah melanggar roilen jalan (GSB). Dalam GSB, harus memperhatikan keharmonisan antara bangunan gedung antara bangunan gedung dengan lingkungan sekitarnya, sehingga dalam mendesain bangunan perlu diterapkan ketentuan seperti Garis Sempadan Banguinan (GSB), Koefisien Dasar Bangunan (KDB), Koefisien Luas Bangunan (KLB), Daerah Cadangan untuk Kepentingan Umum dan pagar pembatas. (Sutedi, 2010:226).

Sehubungan dengan latar belakang diatas, peneliti tertarik untuk melakukan penelitian terkait permasalah tersebut dengan judul "Penerapan Perda No 1 Tahun 2015 Tentang Bangunan Gedung Di Kota Bukittinggi." dengan rumusan masalah :

1. Bagaimana Penerapan Perda No 1 Tahun 2015 Tentang Bangunan Gedung Di Kota Bukittinggi?

2. Kendala-kendala yang dihadapi dalam Penerapan Perda No 1 Tahun 2015 Tentang Bangunan Gedung Di Kota Bukittinggi?

\section{Tinjuan Pustaka Implementasi Kebijakan}

Menurut kamus webster (Solichin, 2004:64) implementasi dirumuskan secara pendek bahwa to implement (mengimplementasikan) berarti to provide the means for carrying out (menyediakan sarana untuk melaksanakan sesuatu); to give pratical effect to (menimbulkan dampak/akibat terhadap sesuatu). Terdapat beberapa konsep implementasi kebijakan yang dikemukakan beberapa ahli. Menurut Daniel A. Mazmanian dan paul A. Sabatier (1979) (Solichin, 2004:65) menjelaskan makna implementasi bahwa: "Memahami apa yang senyatanya terjadi sesudah suatu program dinyatakan berlaku atau dirumuskan merupakan fokus perhatian implementasi kebijaksanaan, yakni kejadian-kejadian dan kegiatan yang timbul sesudah disahkannya pedomanpedoman kebijaksaan negara, yang mencakup baik usaha-usaha untuk mengadministrasikannya maupun untuk menimbulkan akibat/dampak nyata pada masyarakat atau kejadian-kejadian"

Van Meter dan Van Horn (Mulyadi, 2015:57) merumuskan implementasi kebijakan sebagai: "Tindakan-tindakan yang dilakukan oleh badan publik yang diarahkan untuk mencapai tujuan-tujuan yang telah ditetapkan dalam serangkaian keputusan sebelumnya. Tindakan-tindakan ini mencakup usaha untuk mengubah keputusan menjadi tindakan operasional dalam kurun waktu tertentu maupun dalam rangka melanjutkan usaha menapai perubahan besar dan kecil yang ditetapkan oleh keputusan-keputusan kebijakan."

Dari penjelasan diatas dapat disimpulkan bahwa implementasi kebijakan adalah wujud nyata dari suatu kebijakan dan terdapat usaha yang dilakukan agar pelaksaan sebuah 


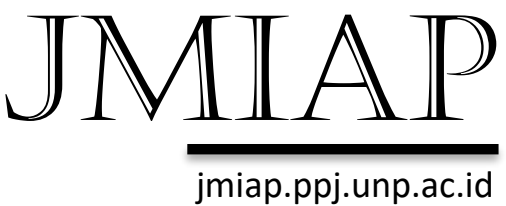

keputusan atau kebijakan dapat mencapai tujuan dari kebijakan itu sendiri.

\section{Model-Model Implementasi Kebijakan}

Solichin (Nisaa, 2017:16-17) kategori implementasi yang luas berupaya mengembangkan teori (analytical framework) yang mengidentifikasi faktorfaktor yang memberikan kontribusi pada terwujud atau tidaknya tujuan kebijakan yang telah digariskan. George C. Edward (Mulyadi, 2015: 68-69) mengemukakan empat variabel yang mempengaruhi kebijakan yakni, komunikasi, sumberdaya, disposisi, dan sruktur organisasi.

1) Komunikasi

Komunikasi berkenaan dengan bagaimana kebijakan dikomunikasikan kepada organisasi dan/atau publik dan sikap serta tanggapan dari pihak yang terlibat. Secara umum Edward (Ratri, 2014: 5) membahas tiga hal penting dalam proses komunikasi kebijakan yaitu transmisi, konsisten dan kejelasan. Transmisi mengkehendaki agar kebijakan disampaikan tidak hanya kepada aktor pelaksana kebijakan, namun disampaikan juga kepada kelompok sasaran kebijakan dan pihak lain yang berkepentingan baik langsung ataupun tidak langsung terhadap kebijakan. Kejelasan kebijakan yang ditransmisikan pada pihak terkait diterima dengan jelas sehingga mereka mengetahui apa yang menjadi maksud, tujuan dan sasaran serta substansi dari kebijakan. Konsisten, apabila menginginkan proses implementasi menjadi efektif diperlukan perintah-perintah yang konsisten dan jelas karena ketidakkonsistenan perintah akan mendorong para aktor pelaksana akan mengambil tindakan yang longgar dalam mengimplementasikan kebijakan.

2) Sumberdaya

Sumberaya berkenaan dengan ketersediaaan sumberdaya pendukung, khususnya sumberdaya manusia. Dimana
JURNAL ILMU ADMINISTRASI PUBLIK

Email : jianfis.unp@gmail.com Vol. 1 No. 1 Tahun 2018

hal ini berkenaan dengan kecakapan dari pelaksana kebijakan untuk carry out kebijakan secara efektif. Apabila kebijakan di komunikasikan dengan baik, tetapi implementor kekurangan sumberdaya untuk melaksanakan, maka implementasi kebijakan tidak akan berjalan secara efektif.. Begitupun sumberdaya lain seperti sumberdaya financial. Sumberdaya financial adalah kecakapan modal investasi atas sebuah program/kebijakan. Sumberdaya financial menjamin keberlangsungan program/kebijakan. Tanpa adanya dukungan financial yang memadai, program tidak dapat berjalan efektif dan cepat dalam mencapai tujuan dan sasaran.

3) Disposisi

Disposisi adalah watak dan karakteristik yang dimiliki oleh implementor, seperti komitmen, kejujuran, sifat demokratis. Disposisi implementor mencakup respon implementor terhadap kebijakan yang akan mempengaruhi kemauan untuk melaksanakan kebijakan. Sikap pelaksana menjadi faktor penting dalam pendekatan mengenai studi implementasi kebijakan publik. Aktor pelaksana tidak hanya harus mengetahui apa yang harus dilakukan dan memiliki kapasitas untuk melaksanakannya. Kecakapan saja tidak mencukupi tanpa adanya kesediaan dan komitmen untuk melaksanakan kebijakan tersebut.

4) Struktur Birokrasi

Struktur organisasi yang bertugas mengimplementasikan kebijakan memiliki pengaruh terhadap impelemntasi kebijakan. Salah satu aspek struktur yang penting di setiap organisasi adalah prosedur-prosedur kerja , ukuran-ukuran dasar atau Standard Operating Procedures (SOP) dan fragmentasi. Sop menjadi pedoman bagi setiap implementor dalam melakukan tindakan. SOP mampu menyeragamkan tindakan-tindakan dari 
birokrasi yang kompleks. Fragmentasi menegaskan bahwa struktur organisasi yang kompleks dan rumit dapat meningkatkan gagalnya komunikasi. Ini pada gilirannya menyebabkan aktivitas organisasi tidak fleksibel.

\section{Izin mendirikan bangunan}

Menurut Sjachran Basah (Sutedi, 2010:170) izin adalah perbuatan hukum administrasi negara bersegi satu yang mengaplikasikan peraturan dalam hal konkret berdasarkan persyaratan dan prosedur sebagaimana ditetapkan oleh ketentuan peraturan perundang-undangan. Secara teori SF Marbun (Rahmi, 2014:36) "Izin didefenisikan sebagai suatu perbuatan administrasi negara yang memperkenankan perbuatan yang secara umum tidak dilarang dalam peraturan perundang-undangan asalkan dilakukan sesuai dengan syarat-syarat tertentu yang ditentukan dalam peraturan hukum yang berlaku.

N.M. Spetl dan J.B.J.M ten Berge (Sutedi, 2010:171) mendefenisikan izin dalam arti sempit yakni pengikatanpengikatan suatu peraturan izin pada umunya didasarkan pada keinginan pembuat undang-undang untuk mencapai suatu tatanan tertentu atau untuk menghalangi keadaan-keadaan yang buruk. Hal pokok pada izin dalam arti sempit bahwa suatu tindakan dilarang terkecuali diperkenankan dengan tujuan agar dalam ketentuan yang disangkutkan dengan perkenan dapat dengan teliti diberikan batas-batas tertentu bagi setiap kasus.

Secara yuridis pengertian izin dan perizinan tertuang dalam Pasal 1 angka 8 dan 9 Peraturan Menteri Dalam Negeri Nomor 24 Tahun 2006 tentang Pedoman Pelayanan Terpadu Satu Pintu. Dalam Pasal 1 angka 8 ditegaskan bahwa; "Izin adalah dokumen yang dikeluarkan oleh peraturan Pemerintah Daerah berdasarkan peraturan daerah atau peraturan lainnya yang merupakan bukti legalitas, menyatakan sah atau diperbolehkannya seseoang atau badan untuk melakukan suatu usaha atau kegiatan tertentu." Pasal 1 angka 9 menegaskan bahwa; "Perizinan adalah pemberian legalitas kepada seseorang atau pelaku usaha/kegiatan tertentu, baik dalam bentuk izin maupun tanda daftar usaha."

Izin mendirikan bangunan dalam pasal 1 angka 21 Peraturan Daerah Kota Bukittinggi No 1 Tahun 2015 tentang Bangunan Gedung ditegaskan bahwa; "Izin mendirikan bangunan yang selanjutnya disingkat IMB adalah perizinan yang diberikan oleh Pemerintah Daerah kepada pemilik bangunan untuk membangun baru, mengubah, memperluas, dan/atau mengurangi bangunan gedung sesuai dengan persyaratan administrasi dan teknis yang berlaku." Perizinan yang berkaitan dengan pemanfaatan ruang terutama adalah izin mendirikan bangunan. Adanya IMB berfungsi supaya Pemerintah Daerah dapat mengontrol dalam rangka pendataan fisik kota sebagai dasar yang sangat penting bagi perencanaan, pengawasan, dan penertiban pembangunan kota yang terarah dan sangat bermanfaat pula bagi pemilik bangunan karena memberikan kepastian hukum atas berdirinya bangunan yang bersangkutan dan akan memudahkan bagi pemilik bangunan untuk suatu keperluan, antara lain dalam hal pemindahan hak bangunan kepada pihak lain. Apabila terjadi izin membangun yang melanggar rencana tata ruang akan dikenakan tindakan berupa, pencabutan izin mendirikan bangunan.

IMB dilaksanakan dengan mendasarkan pada surat KRK/advice planning untuk lokasi yang bersangkutan. Pemerintah daerah wajib memberikan surat KRK secara cuma-cuma untuk lokasi yang bersangkutan kepada setiap orang yang 


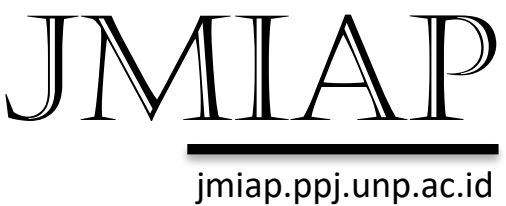

akan mengajukan permohonan IMB sebagai dasar penyusunan rencana teknis bangunan gedung.

Surat KRK merupakan ketentuan yang berlaku untuk lokasi yang bersangkutan dan berisi diantara lain;

1. Fungsi bangunan gedung yang dapat dibangun pada lokasi bersangkutan

2. Ketinggian/jumlah maksimum bangunan gedung yang diizinkan di atas permukaan tanah

3. Jumlah lantai/lapis bangunan di bawah permukaan permukaan tanah dan KTB yang diizinkan

4. Garis sempadan dan jarak bebas minimum bangunan gedung yang diizinkan

5. KDB maksimum yang diizinkan

6. KLB maksimum yang diizinkan

7. KDH minimum yang diwajibkan

8. KTB maksimum yang diizinkan

9. Jaringan utilitas kota

\section{Persyaratan Bangunan Gedung}

Dalam pasal 11 peraturan daerah kota Bukittinggi no 1 tahun 2015 tentang bangunan gedung menjelaskan setiap bangunan gedung harus memenuhi persyaratan administratif dan persyaratan teknis sesuai dengan fungsi banguna gedung. Persyaratan administratif bangunan gedung meliputi:

1. Status dan hak tanah dan/ izin pemanfaatan dari pemegang hak atas tanah

2. IMB

Sedangkan persyaratan teknis bangunan gedung meliputi:

1. Persyaratan tata bangunan dan lingkungan yang terdiri dari

a) Persyaratan peruntukan lokasi

b) Intensitas bangunan gedung

c) Arsitektur bangunan gedung

d) Hasil perhitungan konstruksi untuk bangunan tertentu
JURNAL ILMU ADMINISTRASI PUBLIK

Email : jianfis.unp@gmail.com

Vol. 1 No. 1 Tahun 2018

e) Pengendalian dampak lingkungan untuk bangunan tertentu

f) Rencana tata bangunan dan lingkungan, termasuk kawasan yang termasuk kedaam peraturan Walikota tentang RTLB

2. Persyaratan keandalan bangunan gedung

a) Kepastian kenyamanan

b) Kepastian kesehatan

c) Kepastian keselamatan

d) Kepastian kemudahan aksesibilitas

\section{Manfaat Izin Mendirikan Bangunan}

Dalam Peraturan MENDAGRI Nomor 32 Tahun 2010 tentang Pedoman Pemberian Izin Mendirikan Bangunan Pasal 3 bahwa Manfaat pemberian izin yaitu,

1. Bupati/Walikota memanfaatkan pemberian IMB untuk:

a) Pengawasan, pengendalian, dan penertiban bangunan

b) Mewujudkan tertib penyelenggaraan bangunan yang menjamin keandalan bangunan dari segi keselamatan, kesehatan, kenyamanan, dan kemudahan;

c) Mewujudkan bangunan yang fungsional sesuai dengan tata bangunan dan serasi dengan lingkungannya; dan

d) Syarat penerbitan sertifikasi laik fungsi bangunan.

2. Pemilik IMB mendapat manfaat untuk

a) Pengajuan sertifikat laik jaminan fungsi bangunan;

b) Memperoleh pelayanan utilitas umum seperti pemasangan atau penambahan jaringan listrik, air minum, telepon, dan gas.

\section{Metode Penelitian}

Penelitian ini menggunakan metode kualitatif deskriptif. Dalam hal ini penulis akan mendeskripsikan secara lengkap 


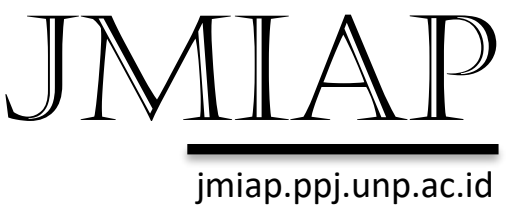

penerapan perda no. 1 tahun 2015 tentang bangunan gedung di Kota Bukittinggi dan kendala-kendala yang dihadapi dalam menerapkan kebijakan tersebut. Lokasi penelitian ini dilakukan di beberapa tempat yang memang diindikasi berkaitan dengan penelitian yang peneliti lakukan yaitu di Kota Bukittinggi, Dinas Pekerjaan Umum dan Penataan Ruang, dan Dinas Penanaman Modal, Pelayanan, Terpadu Satu Pintu Perindustrian dan Tenaga Kerja. Teknik pengumpulan data dalam penelitian ini dilakukan dengan interview (wawancara), observasi (pengamatan).

Informan dalam penelitian ini dipilih secara purposive berdasarkan karakteristik tertentu. Informan penelitian ini yaitu kepala bidang tata ruang, kasi penataan ruang, kasi pengawasan dan pengendalian dinas pekerjaan umum dan penataan ruang, kemudian kepala bidang pelayanan perizinan sektor B dinas penanaman modal, pelayanan terpadu satu pintu, perindustrian dan tenaga kerja serta masyarakat yang dapat memberikan informasi. Teknik keabsahan data menggunakan teknik triangulasi. Sedangkan teknik analisis data yang digunakan dalam penelitian ini adalah pengumpulan data, reduksi data, penyajian data dan penarikan kesimpulan.
JURNAL ILMU ADMINISTRASI PUBLIK

Email : jianfis.unp@gmail.com Vol. 1 No. 1 Tahun 2018

\section{Hasil Penelitian dan Pembahasan}

Penerapan Perda No 1 Tahun 2015 Tentang Bangunan Gedung Di Kota Bukittinggi

Berdasarkan penelitian yang telah peneliti lakukan di lapangan Penerapan Perda No 1 Tahun 2015 Tentang Bangunan Gedung Di Kota Bukittinggi ini belum terlaksana dengan efektif dengan didapat beberapa temuan, sebagai berikut:

Salah satu kebijakan yang dibuat oleh pemerintah daerah Kota Bukittinggi adalah peraturan daerah no 1 tahun 2015 tentang bangunan gedung, dimana dalam peraturan dijelaskan bahwa setiap bangunan gedung wajib memiliki izin mendirikan bangunan (IMB). Di dalam peraturan daerah tersebut dijelaskan juga bahwa sebelum mengurus IMB, pemohon IMB terlebih dahulu mengurus advice planning/KRT. Advice planning berguna untuk mengatur mengenai tujuan membangun dan agar supaya bangunan tata kota teratur dan sesuai peruntukan lahan. Dengan adanya Advice planning ini dapat diketahui batasan lahan yang mana bisa dibangun. Berikut peruntukan lokasi atau kawasan sudah diatur dalam peraturan daerah Kota Bukittinggi nomor 6 tahun 2011 tentang RTRW Kota Bukittinggi.

Tabel 1. Penetapan kawasan strategis Kota Bukittinggi

\begin{tabular}{|c|l|l|l|l|l|}
\hline No & $\begin{array}{l}\text { Kategori } \\
\text { Kawasan }\end{array}$ & Tipologi & \multicolumn{1}{|c|}{ Lokasi } & Tolak Ukur & Arahan Pengawasan \\
\hline 1 & $\begin{array}{l}\text { Rawan } \\
\text { bencana } \\
\text { longsor dan } \\
\text { gerakan tanah }\end{array}$ & $\begin{array}{l}\text { Kawasan } \\
\text { bencana alam }\end{array}$ & $\begin{array}{l}\text { Kawasan sekitar } \\
\text { ngarai sianok }\end{array}$ & $\begin{array}{l}\text { a. Tingkat kelongsoran } \\
\text { ngarai } \\
\text { b. Okupasi lahan } \\
\text { sempadan ngarai } \\
\text { sianok }\end{array}$ & $\begin{array}{c}\text { a. pemanfaatan kawasan } \\
\text { sempadan ngarai sianok } \\
\text { b. pengendalian pembangunan di } \\
\text { kawasan kendali ngarai sianok } \\
\text { c. pemanfaatan teknologi }\end{array}$ \\
\hline
\end{tabular}




\begin{tabular}{|c|c|c|c|c|c|}
\hline 2 & $\begin{array}{l}\text { Kawasan jam } \\
\text { gadang dan } \\
\text { sekitarnya }\end{array}$ & $\begin{array}{l}\text { Kawasan } \\
\text { ekonomi } \\
\text { regional, } \\
\text { pusat orientasi } \\
\text { wisata, simpul } \\
\text { kegiatan }\end{array}$ & $\begin{array}{l}\text { Jam gadang, pasar } \\
\text { atas dan pasar } \\
\text { bawah }\end{array}$ & $\begin{array}{l}\text { a. Simpul dan } \\
\text { orientasi } \\
\text { pergerakan } \\
\text { regional yang } \\
\text { cukup tinggi } \\
\text { b. Penumpukan } \\
\text { berbagai fungsi dan } \\
\text { kegiatan utama } \\
\text { kota } \\
\text { c. Keterbatasan lahan }\end{array}$ & $\begin{array}{l}\text { a. Penataan fungsi bangunan dan } \\
\text { sistem sirkulasi kendaraan dan } \\
\text { pejalan kaki } \\
\text { b. Aturan pembangunan } \\
\text { c. Revitalisasi fungsi wisata dan } \\
\text { wajah/ citra kota } \\
\text { d. Pemantapan kawasan } \\
\text { perekonomian }\end{array}$ \\
\hline 3 & $\begin{array}{l}\text { Kawasan } \\
\text { koridor jalan } \\
\text { sudirman dan } \\
\text { sekitarnya }\end{array}$ & $\begin{array}{l}\text { Kawasan kota } \\
\text { tua, militer } \\
\text { serta taman } \\
\text { kota }\end{array}$ & $\begin{array}{l}\text { a. Koridor sudirman } \\
\text { b. Kawasan } \\
\text { lapangan kantin } \\
\text { dan belakang } \\
\text { balok }\end{array}$ & \begin{tabular}{|l} 
a. \\
tua dan bersejarah \\
b. Adanya kawasan \\
hijau utama kota \\
sebagai perwujudan \\
citra kota wisata
\end{tabular} & $\begin{array}{l}\text { a. revitalisasi kawasan koridor } \\
\text { jaringan jalan sudirman } \\
\text { b. aturan pembangunan koridor } \\
\text { jalan sudirman dan kawasan } \\
\text { sekitarnya }\end{array}$ \\
\hline 4 & $\begin{array}{l}\text { Pusat } \\
\text { pelayanan } \\
\text { primer baru }\end{array}$ & $\begin{array}{l}\text { Kawasan } \\
\text { komersial } \\
\text { utama kota } \\
\text { dan kawasan } \\
\text { pelayanan } \\
\text { umum }\end{array}$ & $\begin{array}{l}\text { a. Kawasan } \\
\text { komersial } \\
\text { Simpang Aur } \\
\text { b. Kawasan koridor } \\
\text { Jl. Soekarno } \\
\text { Hatta } \\
\text { c. Koridor By Pass } \\
\text { d. Kawasan Gulai } \\
\text { Bancah } \\
\text { e. Kawasan pusat } \\
\text { pelayanan umum } \\
\text { baru Pakan } \\
\text { Labuah }\end{array}$ & $\begin{array}{l}\text { a. Kegiatan utama } \\
\text { perdagangan } \\
\text { regional dan skala } \\
\text { kota } \\
\text { b. Pelayanan umum } \\
\text { utama kota }\end{array}$ & $\begin{array}{l}\text { c. Pembangunan kawasan } \\
\text { komersial simpang Aur ke arah } \\
\text { tenggara } \\
\text { d. Pengembangan koridor } \\
\text { komersial } \\
\text { e. Pembangunan pusat pelayanan } \\
\text { umum baru }\end{array}$ \\
\hline 5 & $\begin{array}{l}\text { Kawasan } \\
\text { wisata alam }\end{array}$ & $\begin{array}{l}\text { Kawasan } \\
\text { potensial } \\
\text { wisata dan } \\
\text { ekonomis }\end{array}$ & $\begin{array}{l}\text { Kawasan Panorama } \\
\text { Baru }\end{array}$ & $\begin{array}{l}\text { a. Potensi alam } \\
\text { b. Potensi wisata } \\
\text { c. Pusat } \\
\text { pengembangan } \\
\text { prasarana wisata }\end{array}$ & $\begin{array}{l}\text { a. Pengembangan rute wisata } \\
\text { alam } \\
\text { b. Arahan pemanfaatan ruang } \\
\text { kawasan wisata } \\
\text { c. Pengembangan pusat pelayanan } \\
\text { wisata dan objek wisata }\end{array}$ \\
\hline
\end{tabular}

Sumber: perda nomor 6 tahun 2011 tentang RTRW kota Bukittinggi tahun 2010-2030

Dari tabel diatas tampak bahwa kawasan-kawasan yang telah ditetapkan adalah kawasan yang penataan ruangnya diprioritaskan karena mempunyai pengaruh yang sangat penting dalam lingkup kota terhadap pertanahan dan keamanan, sosial, ekonomi budaya dan lingkungan. Berdasarkan wawancara yang dilakukan dengan kasi penataan ruang, masyarakat tidak mematuhi peraturan dengan mendirikan bangunan didaerah di daerah yang tidak diperuntukan seperti di daerah sepanjang sempadan ngarai yang sebenarnya tidak sesuai peruntukan lahan dan akan membahayakan keselamatan.
IMB yang sudah diatur dalam peraturan daerah No. 1 tahun 2015 tentang bangunan gedung sangatlah penting, baik itu untuk mendirikan bangunan baru, menambah bangunan dan merehap bangunan gedung, tidak ada pengeculian untuk siapa pun yang akan memanfaatkan ruang dan lahan.Tetapi dalam pelaksanaan peraturan tersebut, sebagaimana observasi yang telah dilakukan, masih ditemukan bangunan yang dibangun tanpa mengurus izin.

Menurut George C. Edward III (Mulyadi, 2015: 68-69) ada beberapa variabel yang berperan penting dalam 


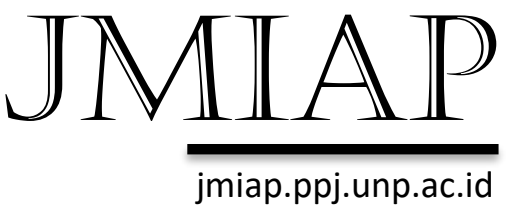

mencapai keberhasilan atau kegagalan suatu implementasi. Adapun variabelvariabel tersebut dapat diidentifikasikan sebagai berikut:

\section{a. Komunikasi}

Berdasarkan wawancara dengan kepala bidang tata ruang di dinas pekerjaan umum dan penataan ruang bahwa,

Peraturan daerah ini sudah disosialisasikan. Untuk IMB diatur oleh dua peraturan daerah yakni yang pertama perda No 1. Tahun 2015 tentang bangunan gedung yang mengacu kepada petunjuk IMB. Yang kedua perda No. 11 tahun 2017 tentang RTRW yang lebih mengacu kepada tata pengaturan kawasan. Untuk perda yang mengatur RTRW sudah disosialisasikan namun baru satu Kelurahan. Untuk perda tentang bangunan gedung sudah sosisalisasikan, tidak hanya ke masyarakat, ke kantor atau ke dinas sudah kami kirim surat untuk mengatakan apabila ingin membangun bangunan, wajib mengajukan IMB. Untuk masyarakat bentuk sosialisasi yang kami lakukan adalah kami adakan pertemuan, kami juga membuat papan peringatan dan untuk tahun ini akan membuat baliho yang berisi informasi tata ruang.

Dari hasil wawancara di atas dapat disimpulkan bahwa komunikasi telah dilakukan ditandai dengan adanya sosialisasi mengenai kebijakan ini yang sudah bersifat aktif seperti adanya sosialisasi kepada masyarakat dengan mengadakan pertemuan dengan beberapa tokoh masyarakat dan membuat papan peringatan yang berisi informasi tentang bangunan gedung, bahkan ke dinas atau instansi lain juga diberitahu mengenai peraturan yang mengatur tentang IMB. Dan ketika dilakukan observasi, penulis
JURNAL ILMU ADMINISTRASI PUBLIK

Email : jianfis.unp@gmail.com Vol. 1 No. 1 Tahun 2018

menemukan bentuk sosialisasi yang dilakukan oleh dinas pekerjaan umum dan penataan ruang berupa papan peringatan yang berisi informasi mengenai IMB.

Namun berdasarkan wawancara yang peneliti lakukan kepada masyarakat, sosialisasi dalam implementasi peraturan ini kurang berjalan dengan baik. Tidak semua masyarakat yang mengetahui peraturan mengenai IMB. Adapun sebagian masyarakat mengetahui peraturan ini tetapi masyarakat tersebut tidak memahami makna dan tujuan dari peraturan terkait IMB, sehingga banyak masyarakat yang tidak mematuhi peraturan.

\section{b. Sumber Daya}

Sumber daya berkenaan dengan sumber daya pendukung berjalannya suatu kebijakan atau peraturan. Sumber daya dapat berupa fasilitas dan tenaga pelaksana. Berdasarkan wawancara yang peneliti lakukan dengan kepala bidang pelayanan perizinan sektor B bahwa,

Kadang kondisi dalam menjalankan tugas staf yang dimiliki banyak namun terasa sedikit. Tidak hanya IMB saja yang diproses oleh dinas perizinan, ada izin pemakaian alat berat, ada izin mendirikan bangunan, dan masih banyak izin yang diproses disini. Kemudian untuk sarana dan prasarana disini juga ada, Cuma tidak mencukupi dan bisa dibilang tidak memadai. Kadang ada komputer yang kondisinya hang sehingga tidak cukup untuk melaksanakan tugas. Kesulitan dari teman-teman juga kadang ada Cuma aspeknya tidak cukup dan tidak memadai untuk digunakan. sumber daya yang dimiliki dinas penanaman modal, pelayanan terpadu satu pintu, perindustrian dan tenaga kerja dan dinas pekerjaan umum dan penataan ruang, baik itu sumberdaya manusia maupun sumberdaya finansial untuk menunjang dan mendukung 


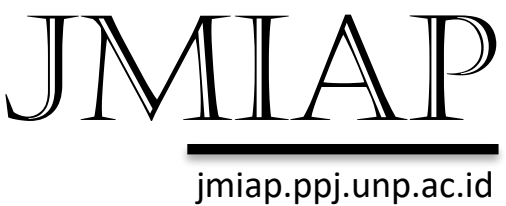

implementasi kebijakan pemerintah daerah Kota Bukittinggi tentang izin mendirikan bangunan gedung ini terbatas dan kurang memadai.

Hal yang senada dengan hasil wawancara dengan kepala bidang tata ruang bahwa,

Disini kan namanya bidang tata ruang. Dimana disiplin ilmu intinya itu teknik perencanaan wilayah dan kota. Kalau dilihat dari segi kompetensi disini itu Saya, kemudian kasi penataan ruang. Untuk kasi pengawasan itu tidak S1 dan selebihnya tidak ada S1. Ada pun S1 disiplin ilmunya tidak sesuai, yang mana sebenarnya tidak mendukung untuk menjalankan tupoksi organisasi. Untuk itu Saya harus sedikit ekstra dalam memberikan arahan dan konsep-konsep kepada teman-teman.Dan untuk sarana dan prasarana kita cukup lengkap mulai dari GPS, kamera, dan drone. Kemudian dalam hal koordinasi, kami berkoordinasi dengan dinas penanaman modal, pelayanan terpadu satu pintu, perindustrian dan tenaga kerja karena IMB diterbitkan oleh dinas tersebut. Tetapi di dalam UU bangunan gedung, Perda bangunan gedung menyebutkan bahwa, sebelum mengajukan IMB terlebih dahulu meminta advice planning yang merupakan salah satu syarat mengajukan IMB. Untuk advice planning kota Bukittinggi dikeluarkan oleh dinas pekerjaan umum dan penataan ruang."

Berdasarkan wawancara diatas dapat disimpulkan bahwa sumber daya yang dimiliki OPD terkait, baik itu sumber daya manusia maupun sumber daya finansial berupa sarana dan prasaran belum sepenuhnya menunjang dalam melaksanakan tugas sebagaimana mestinya. Hal ini dapat menghambat dalam mengiimplementasikan kebijakan.

\section{c. Disposisi}

Pengawasan merupakan salah satu komponen penting dalam implementasi peraturan agar dapat berjalan sebagaimana semestinya. Dalam Penerapan Perda No 1 Tahun 2015 Tentang Bangunan Gedung Di Kota Bukittinggi, pengawasan bangunan gedung dilakukan oleh dinas pekerjaan umum dan penataan ruang. Tugas pengawasan dari dinas pekerjaan umum dan penataan ruang seperti mengawasi yang tidak memiliki IMB, mengawasi bangunan yang tidak sesuai IMB, dan kemudian mengawasi tata ruang dan peruntukan. Dari pengawasan dilapangan ditemukan bangunan yang dibangun tanpa IMB dan bangunan yang sudah memiliki IMB, namun bangunan yang dibangun tidak sesuai dengan izin yang telah diterbitkan seperti bangunan yang melanggar GSB.

Namun pengawasan bangunan gedung tersebut belum dapat terlaksana secara sepenuhnya yang ditandai dengan bangunan-bangunan yang dibangun tanpa IMB dan luput dari pengawasan. Hal ini sesuai dengan hasil observasi dilapangan. Terdapat bangunan yang luput dari pengawasan dan tetap berdiri tanpa adanya 


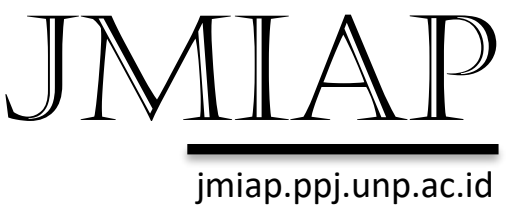

tindak lanjut dari dinas pekerjaan umum dan penataan ruang. Masyarakat yang sedang mendirikan bangunan merasa tidak khawatir mendirikan bangunan tanpa mengurus izin terlebih dahulu karena tidak adanya pengawasan.

\section{d. Struktur Birokrasi}

Berdasarkan hasil wawancara dengan kepala bidang pelayanan perizinan sektor $\mathrm{B}$ di dinas penanaman modal, pelayanan terpadu satu pintu, perindustrian, dan tenaga kerja pada tnaggal 16 agustus 2018 menyatakan bahwa

Dalam pelaksanaan pelayanan perizinan ada yang sesuai dengan SOP dan ada yang tidak sesuai dengan SOP. Hal ini disebakan karena adanya kendala seperti fasilitas ada tapi tidak mencukupi untuk memberikan pelayanan sesuai SOP atau dari segi SDM ada tapi tidak bisa dioptimalkan.

Hal serupa disampaikan oleh kepala bidang tata ruang dinas pekerjaan umum dan penataan ruang, bahwa

Dalam mengeluarkan atau memberikan advice planning kepada masyarakat yang akan mengurus IMB sudah dilakukan sesuai dengan prosedur yang ada, 11 hari untuk advice planning disini dan ditambah lagi pengurusan IMB di dinas perizinan. namun karena adanya anggapan atau setigma negatif bahwa prosedur pelayanan perizinan yang berbelit-belit, kemudian penyelesaian izin yang terlalu lama atau tidak tepat waktu sehingga dapat memicu masyarakat melakukan pelanggaran. Jika dilihat dari segi waktu, untuk mengeluarkan advice planning memang membutuhkan waktu 11 hari karena prosesnya panjang dan
JURNAL ILMU ADMINISTRASI PUBLIK

Email : ¡ianfis.unp@gmail.com Vol. 1 No. 1 Tahun 2018

masih dikerjakan secara konvensional.

Dari wawancara diatas, dapat disimpulkan bahwa pelaksanaan kegiatan berjalan sesuai dengan prosedur yang ada meskipun dalam pelaksanannya mmenemui hambatan seperti sarana dan prasarana penunjang kurang memadai dan membutuhkan proses pengerjaan yang panjang.

\section{Kendala-Kendala yang dihadapi dalam Penerapan Perda No 1 Tahun 2015 Tentang Bangunan Gedung Di Kota Bukittinggi}

Kebijakan pemerintah daerah kota Bukittinggi ini berisi ketentuan yang mengatur berbagai aspek penyelenggaraan bangunan gedung. Salah satu isi kebijakannya tentang IMB. IMB ini bertujuan untuk mewujudkan penyelenggaran bangunan gedung yang berlandaskan pada ketentuan tata ruang, tertib secara administratif dan teknis dan terwujudnya bangunan gedung yang andal, yang menjamin keselamatan, kesehatan, serta serasi dan selaras dengan lingkungan. Menurut George C. Edward III (Mulyadi, 2015: 68-69) ada beberapa variabel yang berperan penting dalam mencapai keberhasilan atau kegagalan suatu implementasi, maka ditemukan kendalakendala dalam implementasi kebijakan izin mendirikan bangunan ini antara lain sebagai berikut:

1. Salah satu kendala yang dihadapi adalah sosialisasi yang tidak merata. Ada masyarakat yang tidak memperoleh informasi mengenai peraturan ini dan ada juga masyarakat yang sudah mengetahui mengenai peraturan IMB namun kurang pemahamannya terkait peraturan. Meskipun sudah ada dilakukan 
sosialisasi, namun masyarakat tidak sepenuhnya memahami secara jelas maksud dan tujuan mengenai peraturan terkait IMB serta pentingya mengurus IMB. Akibatnya tidak sedikit masyarakat yang mengabaikan peraturan dan melakukan pelanggaran.

2. Selanjutnya kendala dari segi sumber daya. Hal ini sesuai dengan hasil wawancara dengan Kepala bidang tata ruang dinas pekerjaan umum dan penataan ruang, yang mengungkapkan bahwa meskipun sarana dan prasaran yang dimiliki dinas pekerjaan umum dan penataan ruang cukup lengkap, namun latar belakang pendidikan sumber daya manusia yang ada di bidang tata ruang kebanyakan tidak sesuai dengan bidang yang mereka jalani, bahkan ada yang pendidikannya tidak sampai S1. selain itu kepala bidang tata ruang juga menambahkan kendala yang dihadapi seperti kurang pemahaman sehingga kepala bidang harus lebih ekstra dalam memberikan arahan-arahan kepada bawahan. Hal ini tentunya berdampak pada pelaksanaan kebijakan. Kemudian hasil wawancara dengan kepala bidang pelayanan perizinan sektor B menyatakan bahwa, sumber daya yang dimiliki dinas penanaman modal, pelayanan terpadu satu pintu, perindustrian dan tenaga kerja tidak memadai dalam pelaksanaan implementasi peraturan. Tidak hanya dari segi sumber daya manusia, kepala bidang pelayanan perizinan sektor B juga mengatakan bahwa sarana dan prasarana juga tidak menunjang dan mendukung implementasi peraturan daerah ini.

3. Selanjutnya kendala yang dihadapi dalam mengimplementasikan peraturan daerah ini adalah kurangnya kemauan masyarakat untuk mematuhi peraturan. Dalam hal ini dimaksud kepada masyarakat yang tidak mematuhi peraturan. Berdasarkan wawancara dengan kasi pengawasan dan pengendalian di dinas pekerjaan umum dan penataan ruang pada tanggal 16 agustus 2018 menyatakan bahwa dari pengawasan dilapangan masih ditemukan bangunan yang dibangun tanpa IMB. ketidak mauan yang di maksud adalah pemilik bangunan gedung tidak punya kesadaran dalam hukum, tidak mempunyai rasa takut atas peraturan dan sanksi yang diberikan pemerintah jika bangunan yang dibangun tidak memiliki IMB, sehingga hal ini membuat bangunanbangunan yang tidak mempunyai IMB sering diberikan peringatan tegas untuk terjalankannya kebijakan daerah tentang IMB tersebut. Selain mendirikan bangunan tanpa izin, bentuk ketidak mauan masyarakat mematuhi peraturan dapat dilihat dari hasil wawancara dengan salah satu masyarakat pemilik bangunan pada tanggal 24 agustus 2018 yaitu,

Saya keberatan dalam membayar retribusi IMB. Saya membangun rumah disebelah bangunan rumah saya yang lama. Memang saya mengurus IMB untuk bangunan rumah saya tersebut, tapi izin yang saya urus itu izin menambah. Jika saya mengurus izin membangun baru biaya yang dikeluarkan mahal. Beda jika saya mengurus izin menambah, biayanya tidak sebesar izin membangun baru.

Dari hasil wawancara diatas dapat simpulkan bahwa adanya persepsi masyarakat yang mengungkapkan bahwa pengurusan IMB mahal, padahal untuk pengurusan dan biaya restribusi telah ditetapkan berdasarkan peraturan yang berlaku, hal tersebut berdampak 


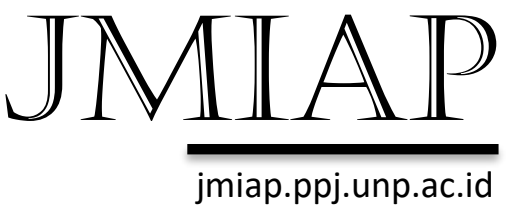

pada kemauan masyarakat untuk mematuhi peraturan.

Hasil penelitian menunjukkan bahwa Penerapan Perda No 1 Tahun 2015 Tentang Bangunan Gedung Di Kota Bukittinggi belum terlaksana sebagaimana mestinya. Sebagaimana IMB yang sudah diatur dalam peraturan daerah No. 1 tahun 2015 tentang bangunan gedung sangatlah penting sebagai acuan bagi masyarakat yang akan mendirikan bangunan. Namun hal ini belum terlaksana sebagaimana mestinya dan berdasarkan observasi yang telah dilakukan, masih ditemukan bangunan yang dibangun tanpa mengurus izin.

Dalam Penerapan Perda No 1 Tahun 2015 Tentang Bangunan Gedung Di Kota Bukittinggi ini tidaklah selalu berjalan baik. Menurut George C. Edward III (Mulyadi, 2015: 68-69) ada beberapa variabel yang berperan penting dalam mencapai keberhasilan atau kegagalan suatu implementasi. Adapun variabelvariabel tersebut dapat diidentifikasikan sebagai berikut:

\section{Komunikasi}

Berdasarkan hasil temuan, komunikasi dalam penerapan peraturan ini kurang berjalan dengan baik sebab tidak semua masyarakat yang mengetahui peraturan mengenai IMB, adapun sebagian masyarakat mengetahui peraturan ini tetapi masyarakat tersebut tidak memahami makna dan tujuan dari peraturan terkait IMB, sehingga banyak masyarakat yang tidak mematuhi peraturan. Komunikasi menunjuk setiap kebijakan akan dapat dilaksanakan dengan baik jika terjadi komunikasi efektif antara pelaksana program (kebijakan) dengan para kelompok sasaran. Hal ini sesuai dengan yang dikemukakan oleh George C. Edward III (Nugroho, 2014:673) menyatakan bahwa komunikasi berkenaan dengan
JURNAL ILMU ADMINISTRASI PUBLIK

Email : jianfis.unp@gmail.com Vol. 1 No. 1 Tahun 2018

bagaimana kebijakan dikomunikasikan kepada organisasi/ publik

2. Sumber daya

Sumber daya untuk menunjang dan mendukung Penerapan Perda No 1 Tahun 2015 Tentang Bangunan Gedung Di Kota Bukittinggi, baik itu dari dinas pekerjaan umum dan penataan ruang dan dinas penanaman modal, pelayanan terpadu satu pintu, perindustrian dan tenaga kerja kurang memadai. Temuan diatas sesuai dengan teori George C. Edward III (Helena Aryu, 2017:12) Sumber daya yang penting meliputi staf dalam ukuran yang tetap dengan keahlian yang diperlukan, informasi yang cukup dan relevan tentang cara untuk mengimplementasikan kebijakan dan dalam penyesuaian lainnya yang terlibat di dalam implementasi, kewenangan untuk menyakinkan bahwa kebijakan ini dilakukan semuanya sebagaimana dimaksudkan dan berbagai fasilitas (termasuk bangunan, peralatan, tanah dan persediaan) didalamnya atau dengan memberikan pelayanan.

3. Disposisi

Pengawasan merupakan sesuatu yang diharuskan dimiliki pelaksana kebijakan. Dalam Penerapan Perda No 1 Tahun 2015 Tentang Bangunan Gedung Di Kota Bukittinggi, kurangnya pengawasan bangunan gedung dari dinas pekerjaan umum dan penataan ruang hal ini tampak tergambar dari hasil wawancara dan observasi lapangan yang telah dilakukan. Temuan penelitian di atas sesuai dengan teori yang dikemukakan oleh George C. Edward III (Riant Nugroho, 2014:673) bahwa disposisi berkenaan dengan kesediaan dari para pelaksana kebijakan untuk carry out kebijakan tersebut karena kecakapan saja tidak mencukupi tanpa kesediaan dan komitmen untuk melaksanakan kebijakan.

4. Struktur birokrasi 
Dalam hal ini dimaksudkan pada pelaksanaan kebijakan sudah dilakukan sesuai dengan prosedur yang ada, meskipun menemui hambatan seperti sarana dan prasarana penunjang kurang memadai. Hal ini sesuai dengan teori yang dikemukakan oleh George C. Edward III (Riant Nugroho, 2014:673) bahwa salah satu aspek struktur yang penting dari setiap organisasi adalah adanya standar operasional prosedur karena standar inilah yang menjadi pedoman bagi setiap implementor dalam bertindak.

Dalam Penerapan Perda No 1 Tahun 2015 Tentang Bangunan Gedung Di Kota Bukittinggi ini tidak berjalan dengan mulus, terdapat kendala-kendala yang dihadapi pelaksana dalam mengimplementasikan peraturan tersebut. Salah satu kendala yang dihadapi adalah sosialisasi yang tidak merata sehingga kurang pemahaman mengenai peraturan. Meskipun sudah ada dilakukan sosialisasi, namun masyarakat tidak memahami secara jelas maksud dan tujuan mengenai peraturan terkait IMB. Kemudian sumber daya untuk menunjang dan mendukung Penerapan Perda No 1 Tahun 2015 Tentang Bangunan Gedung Di Kota Bukittinggi, baik itu dari dinas pekerjaan umum dan penataan ruang dan dinas penanaman modal, pelayanan terpadu satu pintu, perindustrian dan tenaga kerja kurang memadai.

Kendala lainnya adalah kemauan masyarakat untuk mematuhi peraturan. Meskipun peraturan sudah ada, namun masyarakat tidak mau mematuhinya. Dilapangan masih banyak ditemukan bangunan yang didirikan tanpa adanya izin. Masyarakat ada yang tidak menolak dengan tetap mengurus izin tetapi bangunan yang didirikan tidak sesuai dengan ketentuan izin yang diterbitkan.

\section{PENUTUP}

\section{a. kesimpulan}

Berdasarkan hasil penelitian yang dilakukan, dapat disimpulkan bahwa:

1. Penerapan Perda No 1 Tahun 2015 Tentang Bangunan Gedung Di Kota Bukittinggi ini belum berjalan maksimal. Meskipun sudah ada aturan mengenai IMB yang telah dikeluarkan oleh pemerintah daerah, namun pada pelaksanaannya belum berjalan sebagaimana mestinya seperti masyarakat yang mendirikan bangunan yang tidak sesuai dengan peruntukan lokasi, masih ditemukan bangunan yang didirikan tanpa adanya IMB, bangunan yang memiliki IMB namun pada saat dilakukan proses pembangunan, bangunan tersebut tidak sesuai dengan ketentuan izin yang telah diterbitkan, sumberdaya untuk mendukung pelaksanaan peraturan ini kurang memadai, kemudian kurangnya pengawasan bangunan gedung yang dilakukan oleh OPD terkait.

2. Kendala yang dihadapi dalam Penerapan Perda No 1 Tahun 2015 Tentang Bangunan Gedung Di Kota Bukittinggi hal ini dapat dilihat dari permasalahan-permasalahan yang masih ditemukan terkait penerapan peraturan ini. Dari segi komunikasi, masih ada masyarakat yang tidak mengetahui peraturan terkait aturan IMB, adapun sebagian masyarakat mengetahui peraturan ini tetapi tidak memahami tujuan dan makna peraturan terkait IMB, sehingga masyarakat berpotensi melakukan pelanggaran. Dari segi sumber daya yang dimiliki OPD terkait baik sumber daya manusia maupun sumber daya finansial kurang memadai. Serta kemauan masyarakat untuk mematuhi peraturan juga menjadi kendala dalam menerapkan peraturan daerah.

b. Saran

Berdasarkan hasil penelitian dan pembahasan yang telah disimpulkan diatas, 


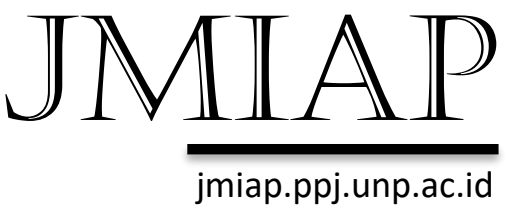

maka peneliti memberikan saran sebagai berikut:

1. Bagi OPD pelaksana peraturan daerah mengenai IMB ini dapat mengkomunikasikan kembali mengenai peraturan daerah agar masyarakat memahami maksud dan tujuan dari peraturan tersebut. Untuk melaksanakan peraturan ini dengan tegas, maka perlu pengawasan bangunan gedung ditingkatkan lagi. Tidak hanya jalan-jalan besar saja yang diawasi, daerah pinggir kota pun harus mendapat pengawasan agar peluang terjadi pelanggaran dapat diminimalisir.

2. Bagi masyarakat agar peka terhadap peraturan daerah. Masyarakat dapat berperan dalam

penyelenggaraan bangunan gedung dengan mengurus IMB sebelum mendirikan bangunan, kemudian jika tampak sebuah pelanggaran maka masyarakat dapat melaporkan sehingga OPD terkait dapat memproses pengaduan tersebut.

\section{Daftar Kepustakaan}

\section{Buku}

Mulyadi, Deddy. 2015. Studi Kebijakan

Publik Dan Pelayanan Publik Konsep

Dan Aplikasi Proses Kebijakan Dan

Pelayanan Publik. Bandung:Alfabeta

Nugroho, Riant. 2014. Public Policy:

Teori, Manajemen, Dinamika, Analisis,

Konvergensi, dan Kimia Kebijakan.

Jakarta: PT Gramedia

Sutedi, Adrian.2010. Hukum Perizinan dalam Sektor Pelayanan Publik.

Jakarta: Sinar Grafika

Wahab, Solichin Abdul. 2004. Analisis kebijaksanaan: Dari Formulasi Ke Implementasi Kebijaksanaan Negara. Jakarta: bumi aksara

Acuan Jurnal/Skripsi/Tesis

Aryu, Helena. 2017. Kebijakan

Pemerintah Daerah Terhadap
JURNAL ILMU ADMINISTRASI PUBLIK

Email : jianfis.unp@gmail.com Vol. 1 No. 1 Tahun 2018

Keberadaan Bangunan di Sempadan Sungai Dalam Perspektif Penataan Ruang DanPerizinan Berdasarkanperda Nomor 11 Tahun 2011Tentang Bangunan Gedung (Studi Kabupaten Sanggau). Jurnal mahasiswa S2 Hukum Universitas Tanjungpura (Untan). Vol 2, No 2 (2017)

Nisaa, Suci Khairun.2017. Implementasi Kebijakan Penerbitan Izin Angkutan Antar Jembput Dalam Provinsi (AJDP) Oleh Dinas Perhubungan Komunikasi Dan Informatika Provinsi Sumatera Barat. Skripsi: Universitas Negeri padang

Ratri, Dewi Kartika. 2014. Implementasi Peraturan Walikota Nomor 36 Tahun 2013 tentang Kebijakan Kota Layak Anak. Jurnal Mahasiswa Ilmu PemerintahanUB,Volume 1 Nomor 2, 10 september 2014

\section{Peraturan-Peraturan Atau Dokumen Pemerintah}

Peraturan MENDAGRI Nomor 32 Tahun 2010 tentang Pedoman Pemberian Izin Mendirikan Bangunan

Peraturan daerah Kota Bukittinggi Nomor 1 Tahun 2015 tentang Bangunan Gedung

Peraturan daerah Nomor 6 tahun 2011 tentang Rencana Tata Ruang Wilayah Kota Bukittinggi tahun 2010-2030

\section{Berita online}

Jontra. 2017. Tidak Miliki IMB, Bangunan Ruko di Pasar Aur Kuning Ini Dibongkar Tim SK4 Pemko Bukittinggi. Gosumbar.com https://www.gosumbar.com/berita/bac a/2017/04/18/tidak-miliki-imbbangunan-ruko-di-pasar-aur-kuningini-dibongkar-tim-sk4-pemkobukittinggi 